\title{
MODEL DATA WAREHOUSE DAN BUSINESS INTELLIGENCE UNTUK MENINGKATKAN PENJUALAN PADA PT. S
}

\author{
Rudy; Natalia Limantara \\ Jurusan Sistem Informasi, Fakultas Ilmu Komputer, Binus University \\ Jl. K.H. Syahdan No.9, Palmerah, Jakarta Barat 11480 \\ rudy@binus.edu; nlimantara@binus.edu
}

\begin{abstract}
Today a lot of companies use information system in every business activity. Every transaction is stored electronically in the database transaction. The transactional database does not help much to assist the executives in making strategic decisions to improve the company competitiveness. The objective of this research is to analyze the operational database system and the information needed by the management to design a data warehouse model which fits the executive information needs in PT. S. The research method uses the Nine-Step Methodology data warehouse design by Ralph Kimball. The result is a data warehouse featuring business intelligence applications to display information of historical data in tables, graphs, pivot tables, and dashboards and has several points of view for the management. This research concludes that a data warehouse which combines multiple database transactions with business intelligence application can help executives to understand the reports in order to accelerate decision-making processes.
\end{abstract}

Keywords: data warehouse, sales, business intelligence, database

\begin{abstract}
ABSTRAK
Banyak perusahaan saat ini telah memanfaatkan sistem informasi dalam kegiatan bisnis. Setiap transaksi yang dilakukan tersimpan secara elektronik di dalam basis data traksaksional. Akan tetapi, basis data transaksional yang ada belum dapat membantu pihak eksekutif membuat keputusan strategis guna meningkatkan daya saing perusahaan.Tujuan penelitian ini adalah menganalisis sistem basis data yang sedang berjalan dan informasi yang dibutuhkan oleh pihak manajemen untuk merancang model data warehouse sesuai kebutuhan informasi eksekutif di PT. S. Metode yang digunakan adalah perancangan data warehouse menggunakan NineStep Methodology menurut Ralph Kimball. Hasil yang dicapai adalah data warehouse yang dilengkapi dengan aplikasi business intelligence untuk menampilkan informasi-informasi bagi pihak manajemen dari data historis dengan format tabel, grafik, pivot tabel, dan dashboard serta memiliki beberapa sudut pandang. Simpulan dari penulisan ini adalah data warehouse yang mengabungkan beberapa database transaksi yang dilengkapi dengan aplikasi business intelligence dapat membantu eksekutif untuk memahami laporan yang dihasilkan guna mempercepat proses pengambilan keputusan.
\end{abstract}

Kata kunci: data warehouse, penjualan, business intelligence, basis data 


\section{PENDAHULUAN}

Perkembangan teknologi informasi yang pesat membuat teknologi informasi dapat dijadikan sebagai salah satu alat untuk bersaing dalam kompetisi usaha. Perusahaan yang dapat menerapkan teknologi informasi dengan efektif dan efisien dapat menjadi lebih unggul dibandingkan dengan perusahaan yang belum dapat memanfaatkannya dengan efektif dan efisien. Saat ini manajemen perusahaan menuntut agar perusahaan memiliki sebuah sistem yang dapat membantu mereka dalam mengambil keputusan. Karena sering kali manajemen dibanjiri oleh banyak sekali data yang menghambat proses pengambilan keputusan.

Untuk memenuhi kebutuhan tersebut, perusahaan mulai mengembangkan sebuah data warehouse untuk menampung data historis perusahaan. Data ini kemudian ditampilkan dalam sebuah aplikasi business intelligence yang dapat menampilkan laporan dalam bentuk grafik dan tabel yang mudah dipahami. Laporan ini dapat digunakan ekekutif perusahaan untuk membuat rencana jangka perusahaan.

PT. S adalah sebuah perusahaan penyedia solusi imaging dan printing yang terpercaya dan berpengalaman selama lebih 25 tahun melayani ratusan bahkan ribuan perusahaan di seluruh indonesia. PT. S memberikan solusi imaging dan printing yang mengintegrasikan perangkat keras, perangkat lunak dan solusi yang ditujukan untuk membantu pelanggan dalam siklus produksi dokumen (print \& copy), distribusi dokumen (fax \& e-mail) dan manajemen dokumen (e-document).

Saat ini PT. S sudah memiliki sebuah aplikasi yang digunakan untuk melakukan transaksi sehari-hari. Namun para eksekutif mereka mengeluhkan waktu yang diperlukan untuk menghasilkan sebuah laporan sederhana saja. Mereka menginginkan sebuah aplikasi yang dapat mengurangi waktu mereka dalam menghasilkan sebuah laporan. Selain itu PT. S memiliki beberapa cabang yang memiliki database sendiri. Hal ini menyulitkan pihak eksekutif untuk memperoleh laporan yang menyeluruh mengenai kinerja perusahaan. Untuk mengatasi beberapa masalah di atas, PT. S dapat menggunakan data warehouse yang dapat mengintegrasikan semua database yang ada dan mempercepat proses untuk menghasilkan sebuah laporan.

\section{Tinjauan Pustaka}

Menurut Inmon (2005, p.495), data warehouse adalah kumpulan dari database yang terintegrasi dan berorientasi subjek serta dirancang untuk mendukung fungsi pengambilan keputusan, dimana setiap unit data relevan terhadap satu kejadian pada waktu tertentu. Data warehouse memiliki beberapa karakteristik utama yaitu subject-oriented 'berorientasi pada subyek', time-variant 'memiliki variasi waktu', non-transactional 'non transaksional', dan integrated 'terintegrasi'.

Untuk merancang sebuah data warehouse diperlukan beberapa tahap perancangan yaitu pemilihan proses, pemilihan grain, identifikasi dan penyesuaian dimensi, pemilihan fakta, peyimpanan pre-calculation di tabel fakta, menambahkan penjelasan pada tabel dimensi, pemilihan durasi database, menentukan metode untuk perubahan dimensi, dan penentuan prioritas dan query mode.

Data akan dipindahkan dari database operasional ke dalam database data warehouse. Pemindahan ini melibatkan proses ekstraksi, transformasi, dan loading. Ekstraksi adalah proses untuk memilih data yang relevan dari operasional database sebelum dimasukkan ke dalam data warehouse. Transformasi adalah proses untuk mengatasi ketidakkonsistenan diantara data-data yang ada. Loading adalah proses perpindahan secara fisik data dari tempat penyimpanan komputer database sumber ke database data warehouse. 
Menurut Whalen (2001, p.236), “Tabel fakta adalah tabel di dalam data warehouse yang menjelaskan ukuran data bisnis. Fakta berisi nilai dari sebuah kejadian atau transaksi tertentu misalnya penyimpanan uang di bank, penjualan produk, atau pesanan. Tabel fakta menyimpan nilai numerik daripada karakter.Tabel dimensi digunakan untuk menyempurnakan data yang ada pada tabel fakta atau menjelaskannya dengan lebih detil. Datanya merupakan karakter.”

Menurut Connolly (2005, p.1018), "Skema bintang adalah sebuah logikal struktur yang mempunyai sebuah tabel fakta berisi data terbaru di tengah, yang dikelilingi tabel dimensi yang berisi data referensi (yang dapat didenormalisasi).”

Menurut Hollander (2000, p. 230), "Penjualan adalah sekumpulan dari kejadian yang secara kolektif ditujukan untuk melayani dan menarik customer, membantu customer dalam memilih barang dan pelayanan terbaik, menyampaikan barang dan palayanan terbaik, dan mengumpulkan pemayaran dari barang dan pelayanan.”

\section{METODE}

Metode perancangan menggunakan Nine-Step Methodology Kimball yang terdiri dari sembilan tahap perancangan data warehouse: choosing the process 'pemilihan proses'; choosing the grain 'pemilihan grain'; identifying and conforming the dimensions 'identifikasi dan penyesuaian dimensi'; choosing the facts 'pemilihan fakta'; storing pre-calculations in the fact table 'penyimpanan pre-calculation di tabel fakta'; rounding out the dimension tables 'memastikan tabel dimensi'; choosing the duration of the database 'pemilihan durasi database'; tracking slowly changing dimensions 'melacak perubahan dari dimensi secara perlahan'; deciding the query priorities and the query modes 'penentuan prioritas dan model query'.

\section{HASIL DAN PEMBAHASAN}

\section{Proses Bisnis Penjualan Berjalan}

PT. S melayani penjualan secara langsung maupun melalui telepon. Pelanggan yang akan membeli barang di PT. S dapat menghubungi bagian penjualan untuk membeli barang yang diinginkan. Bagian penjualan akan membuat sales order tiga rangkap yang berisi barang yang dibeli, kesepakatan harga, dan informasi tentang pelanggan. Rangkap 1 akan diberikan kepada bagian gudang, rangkap 2 akan diberikan kepada bagian penagihan, dan rangkap 3 akan diarsip.

Setelah menerima sales order rangkap 1 dari bagian penjualan, bagian gudang akan menyiapkan barang untuk pengiriman. Setelah barang siap dikirim, bagian gudang akan membuat delivery order dua rangkap. Delivery order ini akan diberikan kepada bagian pengiriman untuk dikirim bersamaan dengan barang kepada pelanggan.

Pelanggan menandatangani delivery order sebagai tanda barang telah sampai. Delivery order rangkap 1 akan diberikan kepada pelanggan dan rangkap 2 akan dibawa oleh bagian pengiriman untuk diberikan kepada bagian penagihan. Setelah menerima delivery order yang sudah ditandatangani, bagian penagihan akan mengecek kesesuaian antara sales order dan delivery order. Setelah itu bagian penagihan akan membuat invoice untuk dikirim ke pelanggan sebagai tagihan. 
Pelanggan dapat membayar tagihan secara langsung ke bagian penagihan atau mentransfer pembayaran. Jika pelanggan mentransfer pembayaran, pelanggan harus mengirimkan bukti transfer ke bagian penagihan.

\section{Proses Bisnis Penyewaan}

Selain menjual barang, PT S juga menyewakan barang mereka. Pelanggan yang ingin menyewa barang di PT S dapat datang ke bagian penyewaan. Bagian penyewaan akan membuatkan contract agreement tiga rangkap yang berisi tentang barang yang disewa, lama kontrak, data pelanggan, fungsi penyewaan dari barang tersebut, dan harga sewa mesin. Contract agreement rangkap 1 akan diberikan ke pelangan, rangkap 2 akan diberikan kepada bagian gudang dan rangkap 3 akan diarsip. Saat contract agreement dibuat, pelanggan harus langsung membayar biaya penyewaan.

Bagian gudang akan menyiapkan barang yang sesuai dengan yang ada di contract agreement. Setelah barang siap dikirim, bagian gudang akan membuat delivery order dua rangkap. Delivery order ini akan diberikan kepada bagian pengiriman untuk dikirim bersamaan dengan barang kepada pelanggan.

Pelanggan harus menandatangani delivery order sebagai tanda barang telah sampai. delivery order rangkap 1 akan diberikan kepada pelanggan dan rangkap 2 akan dibawa oleh bagian pengiriman untuk diberikan kepada bagian penyewaan.

Mesin tertentu yang harus dibayar per penggunaan akan dicek jumlah penggunaannya setiap sebulan sekali atau tiga bulan sekali oleh teknisi dan akan melaporkannya kepada bagian penagihan. Kemudian, bagian penagihan akan membuat invoice untuk menagih penggunaan mesin dan biaya sewa mesin ke pelanggan. Jika mesin tidak memiliki biaya penggunaan, pelanggan hanya membayar saat membuat contract agreement.

Pelanggan dapat membayar tagihan secara langsung ke bagian penagihan atau mentransfer pembayaran. Jika pelanggan mentransfer pembayaran, pelanggan harus mengirimkan bukti transfer ke bagian penagihan. Entity relationship diagram (ERD) pada sistem yang berjalan untuk penjualan dan penyewaan di atas dituangkan dalam Gambar 1 berikut.

\section{Arsitektur Data Warehouse}

Dalam perancangan data warehouse di PT. S, arsitektur yang digunakan adalah centralized data warehouse 'data warehouse terpusat' (Gambar 2). Data yang ada di dalam database operasional perusahaan dipilih berdasarkan kebutuhan pelaporan perusahaan kemudian dipindahkan ke dalam satu tempat penyimpanan yang besar. Namun sebelum disimpan dalam satu tempat, data tersebut ditransformasi terlebih dahulu sehingga data warehouse yang terbentuk menjadi konsisten.

\section{Perancangan Data Warehouse}

\section{Pemilihan Proses}

Berikut adalah proses yang terjadi pada PT. S yang akan digunakan untuk perancangan data warehouse: (1) Penjualan - dokumen yang digunakan dalam proses ini adalah sales order, delivery order, dan invoice. Sedangkan data yang digunakan adalah partner, order, invoice, warehouse, dan product; (2) Penyewaan - dokumen yang digunakan adalah contract agreement, delivery order, dan invoice. Sedangkan data yang digunakan adalah rental contract, rental contract machine, func charge, master functional, cost, dan invoice; (3) Service - dokumen yang digunakan adalah customer agreement, form kunjungan service, dan invoice. Sedangkan data yang digunakan adalah service visit, 
service visit machine, service visit discovery, service visit symptom, service visit part, technician, supervisor, dan technician craft.

\section{Pemilihan Grain}

Pemilihan grain adalah proses untuk menentukan apa yang digambarkan oleh record di dalam tabel fakta. Berikut ini adalah grain yang ada dalam perancangan data warehouse PT S: (1) Penjualan - analisis yang dapat dilakukan pada proses penjualan adalah produk yang paling banyak terjual, kuantitas pembelian produk pelanggan, total penjualan per pelanggan, total penjualan per produk, dan pelanggan yang sering melakukan pembatalan; (2) Penyewaan - analisis yang dapat digunakan pada proses penyewaan adalah produk yang paling sering disewa, total penyewaan per pelanggan dan per produk, fungsi dari produk yang paling sering digunakan oleh pelanggan, fungsi yang sering digunakan dalam setiap produk, informasi mengenai detil fungsi yang sering disewa per produk, per fungsi, dan per detil fungsi, frekuensi pemakaian produk per produk, per fungsi, per detil fungsi, dan per pelanggan, dan biaya pemakaian produk per produk dan per pelanggan; (3) Service - analisis yang dapat dilakukan pada proses service adalah total biaya perjanjian service per pelanggan dan per produk, keahlian yang paling sering diperlukan untuk melakukan service, kuantitas part yang sering diganti per pelanggan dan per part, biaya part yang sering diganti per pelanggan dan per part, produk yang paling sering di-service, masalah yang sering terjadi pada produk berdasarkan produk dan part dan jumlah kunjungan service per pelanggan, per teknisi dan per supervisor.

\section{Identifikasi dan Penyesuaian Dimensi}

Berikut ini adalah penyesuaian dimensi dan grain yang ditampilkan dalam bentuk matriks (lihat tabel 1).

\section{Pemilihan Fakta}

Pada tahap ini dilakukan pemilihan fakta yang akan digunakan. Masing-masing fakta memiliki data yang dapat dihitung dan selanjutnya akan ditampilkan dalam bentuk laporan dan grafik. Berikut adalah fakta-fakta yang akan digunakan dalam data warehouse: (1) fakta penjualan berisi mengenai kuantitas produk yang dijual dan total penjualan; (2) fakta status penjualan berisi mengenai jumlah sales order yang dibatalkan dan jumlah sales order yang berhasil; (3) fakta penyewaan berisi mengenai kuantitas produk yang disewa, total penyewaan, kuantitas fungsi yang disewa, dan kuantitas detil fungsi yang digunakan; (4) fakta Penggunaan mesin berisi tentang frekuensi penggunaan mesin yang disewa dan total biaya penggunaan mesin; (5) fakta service berisi tentang total biaya perjanjian service, keahlian yang paling sering diperlukan untuk melakukan service, kuantitas part yang sering diganti, biaya part yang sering diganti, produk yang paling sering di-service, masalah yang sering terjadi pada produk dan jumlah kunjungan service.

\section{Penyimpanan Pre-calculation di Table Fakta}

Dalam tabel fakta terdapat data yang merupakan kalkulasi awal. Hasil dari kalkulasi ini kemudian akan disimpan dalam tabel fakta: (1) TotalSales, yaitu hasil dari QtyEntered dikali PriceEntered dikurangi diskon dari tabel C_Invoice_Line; (2) TotalMachineUsing, yaitu hasil dari penjumlahan dari QtyEntered dikali PriceEntered tabel C_Invoice_Line; (3) TotalPartService, yaitu hasil dari price dikali quantity dari tabel L_Servicevisit_part.

\section{Memastikan Tabel Dimensi}

Pada tahap ini akan ditambahkan penjelasan tekstual dari tabel dimensi (lihat tabel 2). 


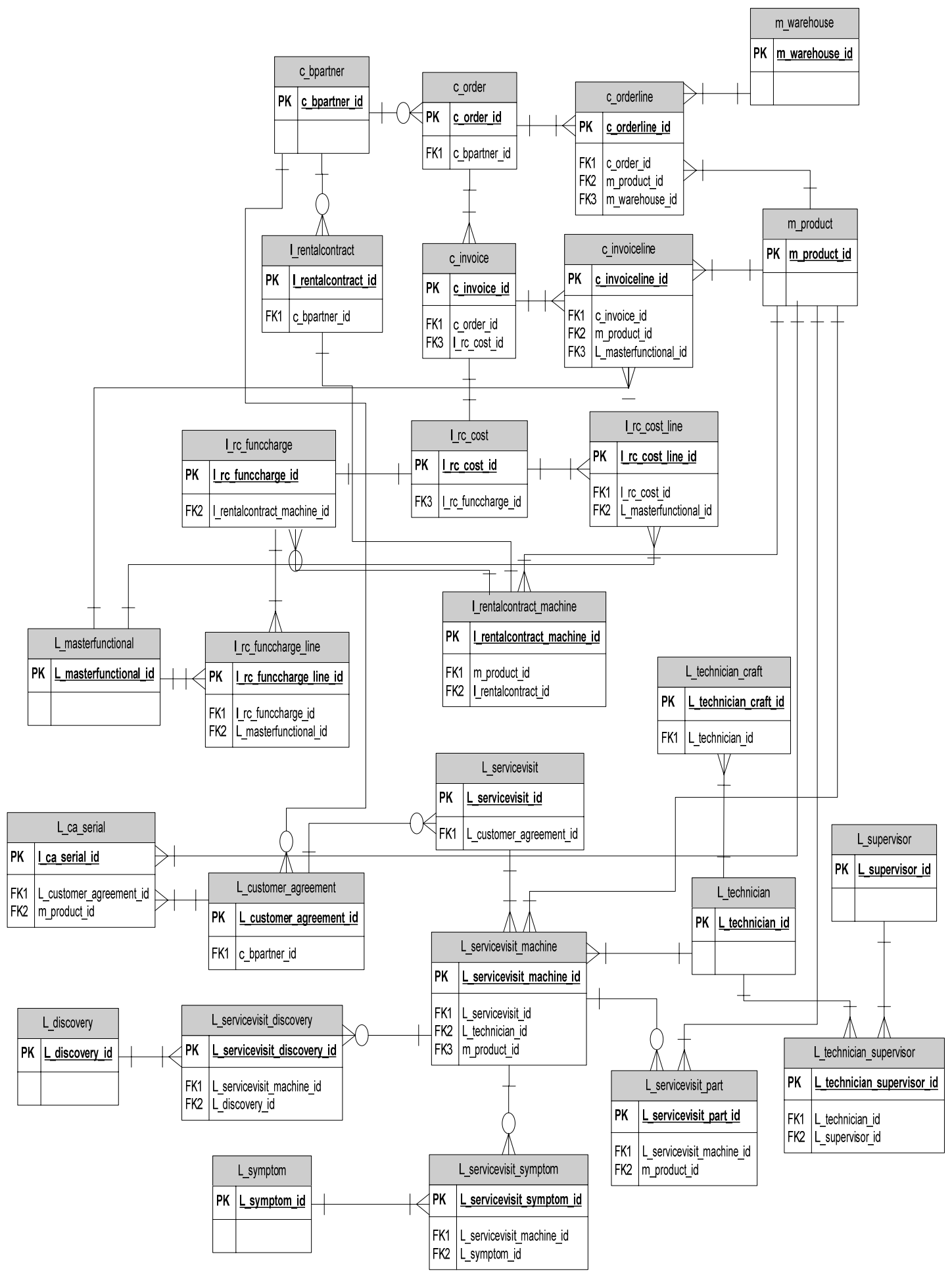

Gambar 1. ERD yang digunakan. 


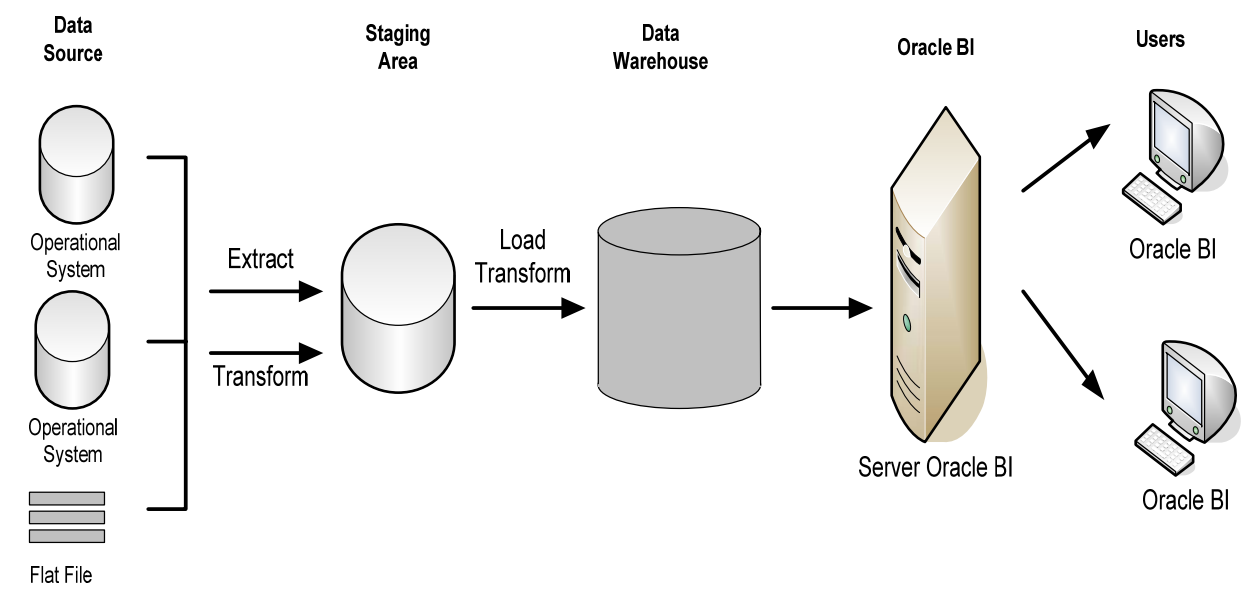

Gambar 2. Arsitektur Data Warehouse PT.S.

Tabel 1

Tabel Dimesi Vs Grain

\begin{tabular}{lccc}
\hline Dimensi & Penjualan & Penyewaan & Service \\
\hline Waktu & $\mathbf{X}$ & $\mathbf{X}$ & $\mathbf{X}$ \\
Partner & $\mathbf{X}$ & $\mathbf{X}$ & $\mathbf{X}$ \\
Product & $\mathbf{X}$ & $\mathbf{X}$ & $\mathbf{X}$ \\
MasterFunctional & & $\mathbf{X}$ & \\
FuncCharge & & $\mathbf{X}$ & \\
Craft & & & $\mathbf{X}$ \\
Part & & & $\mathbf{X}$ \\
Symptom & & & $\mathbf{X}$ \\
Technician & & & $\mathbf{X}$ \\
\hline
\end{tabular}

Tabel 2

Tabel Rounding Out Dimension

\begin{tabular}{|c|c|c|c|}
\hline Dimensi & Field & Deskripsi & Hierarki \\
\hline DimWaktu & $\begin{array}{l}\text { TimeKey } \\
\text { FullDate } \\
\text { DayNumber } \\
\text { WeekNumber } \\
\text { MonthNumber } \\
\text { QuarterNumber } \\
\text { CalenderYear }\end{array}$ & 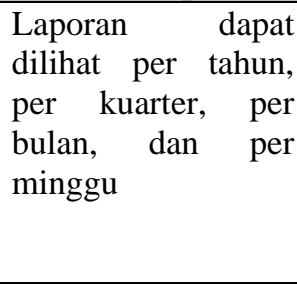 & $\begin{array}{l}\text { Tahun } \\
\text { Kuarter } \\
\text { Bulan } \\
\text { Minggu }\end{array}$ \\
\hline DimPartner & $\begin{array}{l}\text { C_Bpartner_No } \\
\text { C_BPartner_ID } \\
\text { Name } \\
\text { BP_Group } \\
\text { Provinsi } \\
\text { Kota } \\
\text { Flag_Active } \\
\text { Create_Date }\end{array}$ & $\begin{array}{l}\text { Laporan dapat } \\
\text { dilihat per provinsi, } \\
\text { per kota, per group, } \\
\text { dan per partner }\end{array}$ & $\begin{array}{l}\text { Provinsi } \\
\text { Kota } \\
\text { BP_Group } \\
\text { C_BPartner_ID }\end{array}$ \\
\hline DimProduct & $\begin{array}{l}\text { M_Product_ID } \\
\text { Name }\end{array}$ & $\begin{array}{l}\text { Laporan dapat } \\
\text { dilihat per kategori }\end{array}$ & $\begin{array}{l}\text { Product_Category } \\
\text { Brand_Product }\end{array}$ \\
\hline
\end{tabular}




\begin{tabular}{|c|c|c|c|}
\hline & $\begin{array}{l}\text { Product_Category } \\
\text { Brand_Product }\end{array}$ & $\begin{array}{l}\text { produk, per brand } \\
\text { produk, dan per } \\
\text { produk }\end{array}$ & M_Product_ID \\
\hline DimTechnician & $\begin{array}{l}\text { L_Technician_No } \\
\text { L_Technician_ID } \\
\text { Name_Technician } \\
\text { Subterritotial } \\
\text { Name_Supervisor } \\
\text { Territotial } \\
\text { Flag_Active } \\
\text { Create_Date }\end{array}$ & $\begin{array}{lr}\text { Laporan } & \text { dapat } \\
\text { dilihat } & \text { per } \\
\text { subterritorial } & \text { dan } \\
\text { per taknisi } & \end{array}$ & $\begin{array}{l}\text { Territorial } \\
\text { Subterritotial } \\
\text { Name_Supervisor } \\
\text { L_Technician_ID } \\
\text { Craft_ID }\end{array}$ \\
\hline DimPart & $\begin{array}{l}\text { M_Part_ID } \\
\text { Name } \\
\text { Product_Category } \\
\text { Brand_Product }\end{array}$ & $\begin{array}{l}\text { Laporan dapat } \\
\text { dilihat per kategori } \\
\text { part, per brand part, } \\
\text { dan per part }\end{array}$ & $\begin{array}{l}\text { Product_Category } \\
\text { Brand_Product } \\
\text { M_Part_ID }\end{array}$ \\
\hline
\end{tabular}

\section{Pemilihan Durasi Database}

Dalam tahap ini akan ditentukan umur data yang diambil dan yang akan dipindahkan ke dalam tabel fakta. Berdasarkan hasil identifikasi kebutuhan pada PT. S, durasi database yang akan digunakan dalam data warehouse adalah database dari bulan Januari 2007 hingga Agustus 2009. Sehingga data yang ada di dalam data warehouse telah berumur dua tahun delapan bulan.

\section{Melacak Perubahan dari Dimensi secara Perlahan}

Untuk menangani perubahan data pada tabel dimensi akan digunakan teknik slowly changing dimension 2 (SCD 2) dimana jika terjadi perubahan data, record baru akan ditambahkan pada tabel dimensi yang bersangkutan. Sehingga di beberapa tabel dimensi akan ditambahkan surrogate key. Dalam perancangan data warehouse pada PT. S, hanya DimPartner dan DimTechnician yang menggunakan teknik ini. Karena hanya kedua dimensi tersebut yang memungkinkan adanya perubahan data.

\section{Memutuskan Proritas dan Mode dari Query}

Memutuskan proritas dan mode dari query dengan cara: (1) Proses extract, transform, dan loading (ETL) - Proses ETL akan dilakukan setiap sebulan sekali yang akan dilakukan oleh staf divisi IT di perusahaan pusat; (2) Proses backup - Proses backup akan dilakukan sebulan sekali oleh divisi IT sebelum dilakukan proses ETL. Hal ini bertujuan untuk mengantisipasi proses ETL yang gagal; (3) Analisis kapasitas media penyimpanan (Tabel 3).

Tabel 3

Kapasitas Media Penyimpanan

\begin{tabular}{lrrrr}
\hline \multicolumn{1}{c}{ Tabel } & $\begin{array}{c}\text { Besar Record } \\
\text { (bytes) }\end{array}$ & $\begin{array}{c}\text { Jumlah Record } \\
\text { Saat ini }\end{array}$ & $\begin{array}{c}\text { Jumlah Record sampai } \\
\text { 5 tahun }\end{array}$ & $\begin{array}{c}\text { Besar media penyimpanan } \\
\text { (Kbytes) }\end{array}$ \\
\hline FactSales & 110 & 83464 & 239944 & 25775.2 \\
FactSalesOrder & 88 & 123683 & 130643 & 10629 \\
FactContract & 198 & 43872 & 44952 & 8425.05 \\
FactContractCost & 132 & 11469 & 32949 & 4247.33 \\
FactService & 286 & 21468 & 61668 & 17223.7 \\
DimWaktu & 139 & 974 & 2799 & 379.94
\end{tabular}




\begin{tabular}{lrrrr} 
DimPartner & 513 & 684 & 804 & 402.79 \\
DimProduct & 362 & 41 & 66 & 16.89 \\
Dim & 144 & 23 & 23 & 3.23 \\
MasterFunctional & 130 & 4 & 4 & 0.51 \\
DimFuncCharge & 244 & 261 & 311 & 74.11 \\
DimCraft & 382 & 209 & 234 & 87.29 \\
DimPart & 144 & 134 & 184 & 25.88 \\
DimSymptom & 713 & 156 & 186 & 129.51 \\
DimTechnician & & & $67420.45 \mathrm{kbytes}=$ \\
\multicolumn{2}{c}{ Total } & & 65.84 Mbytes
\end{tabular}

\section{Skema Bintang}

Untuk memenuhi kebutuhan informasi pihak manajemen, penulis akan merancang tiga buah skema bintang: skema bintang penjualan (Gambar 3), skema bintang status penjualan (Gambar 4), dan skema bintang penyewaan (Gambar 5).

Skema bintang penjualan untuk menggambarkan transaksi penjualan yang terjadi di PT. S. Dalam skema ini terlihat kuantitas penjualan produk dan pendapatan dari penjualan produk. Data tersebut dapat dilihat berdasarkan DimPartner, Dim Product, atau DimWaktu.

Skema bintang status penjualan yang menggambarkan transaksi penjualan yang dibatalkan atau tidak oleh pelanggan. Dalam skema ini terlihat banyaknya penjualan yang dibatalkan dan berhasil. Data tersebut dapat dilihat berdasarkan DimPartner atau DimWaktu.

Gambar 5 menggambarkan skema bintang penyewaan yang menjelaskan transaksi penyewaan yang terjadi di PT. S. Dalam skema ini terlihat banyaknya mesin yang disewa, pendapatan dari mesin yang disewa, fungsi yang sering digunakan, dan detil fungsi yang sering digunakan. Data tersebut dapat dilihat berdasarkan DimWaktu, DimPartner, DimMasterFunctional, DimFuncCharge, dan DimProduct.

Gambar 6 menggambarkan skema bintang penggunaan mesin yang menjelaskan frekuensi penggunaan mesin yang disewa dan total biaya dari penggunaan mesin tersebut. Data tersebut dapat dilihat berdasarkan DimWaktu, DimPartner, DimMasterFunctional, DimFuncCharge, dan DimProduct.

\section{Tampilan Aplikasi Business Intelligence}

Gambar 7 menggambarkan tampilan layar dashboard untuk dua buah skema yang ada diatas. Pada layar ini menggambarkan gambaran umum dari kondisi perusahaan pada waktu tertentu. Pada bagian kanan atas terdapat speedometer yang menggambarkan kondisi penjualan PT. S dari tahun ke tahun, Pada layar sebelah kiri atas terlihat jumlah penjualan yang dibatalkan dan yang disetujui. Pada layar bagian bawah, pengguna dapat melihat data penjualan yang diinginkan dalam bentuk grafik maupun tabel. Parameter tampilan dapat diubah sesuai dengan kebutuhan pengguna. Aplikasi business intelligence dibuat menggunakan Oracle Business Intelligence Suite Enterprise edition. 


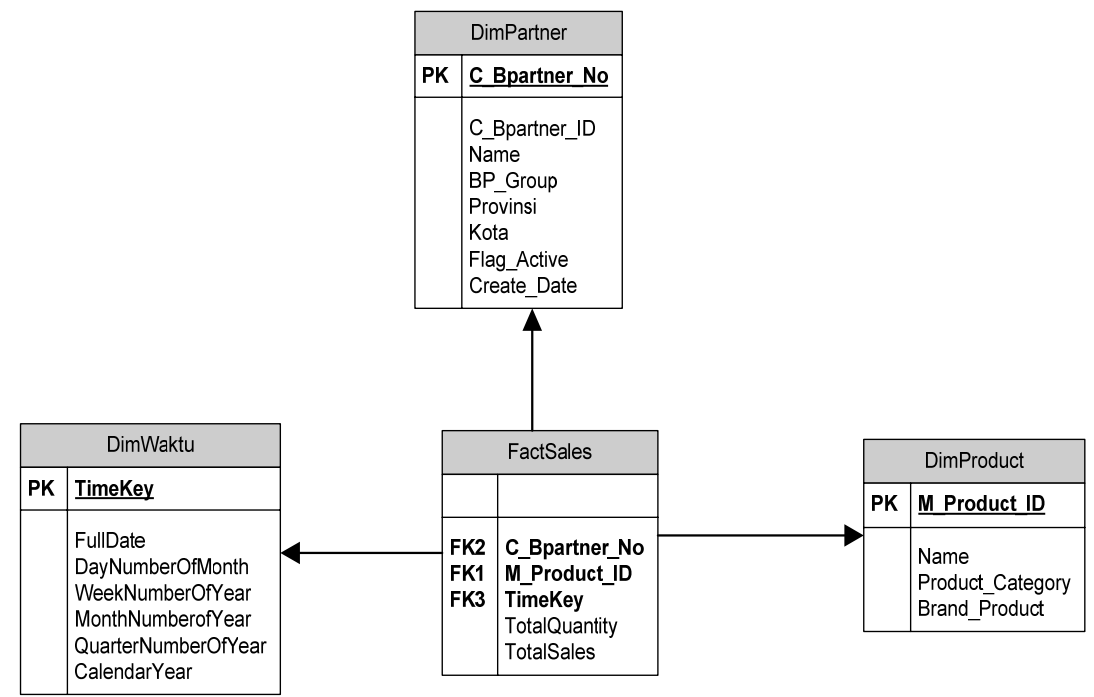

Gambar 3. Skema bintang penjualan.

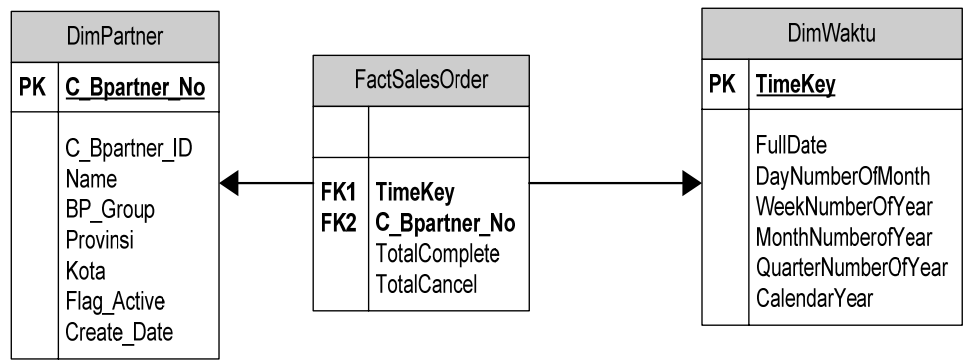

Gambar 4. Skema bintang status penjualan.

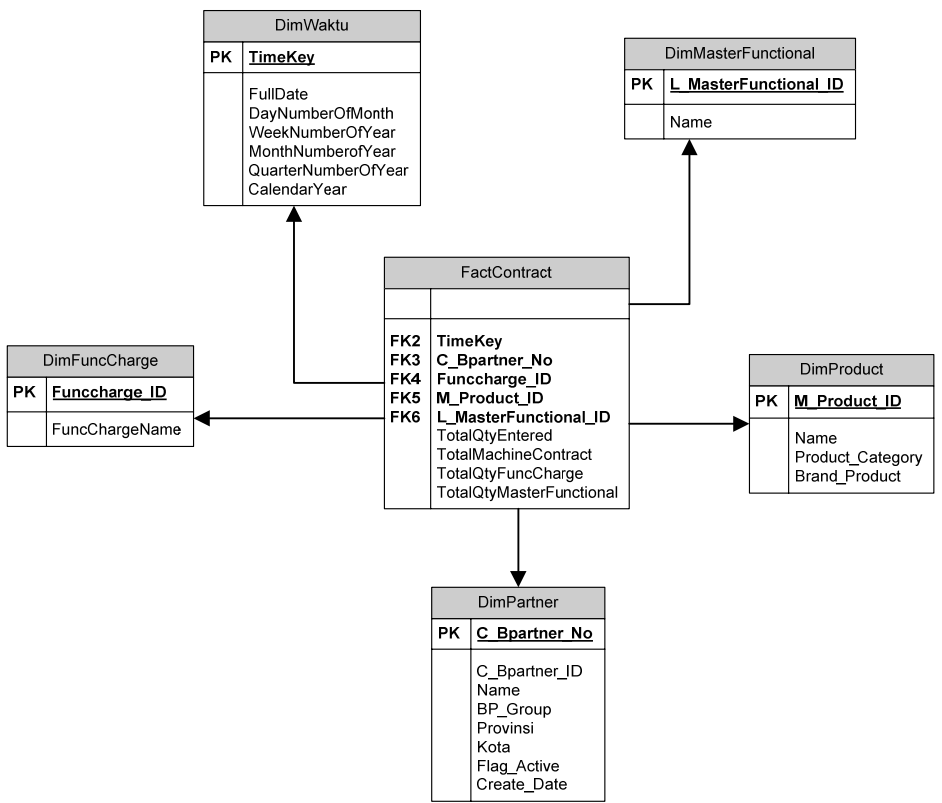

Gambar 5. Skema bintang penyewaan. 


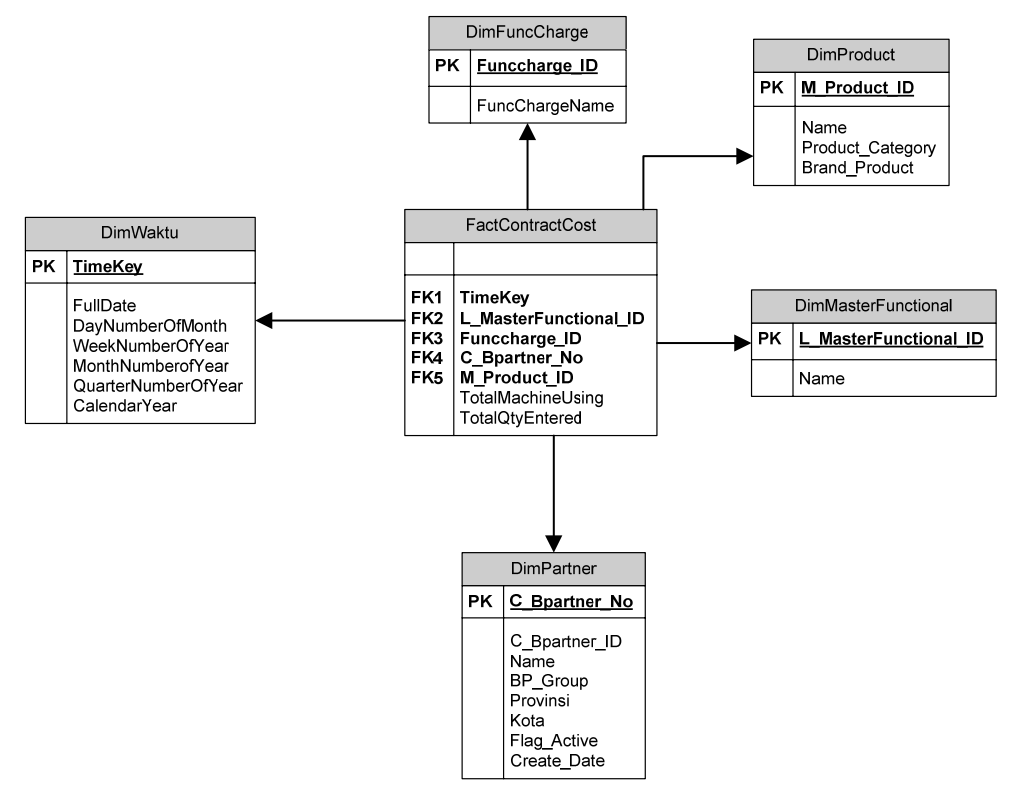

Gambar 6. Skema bintang penggunaan mesin.

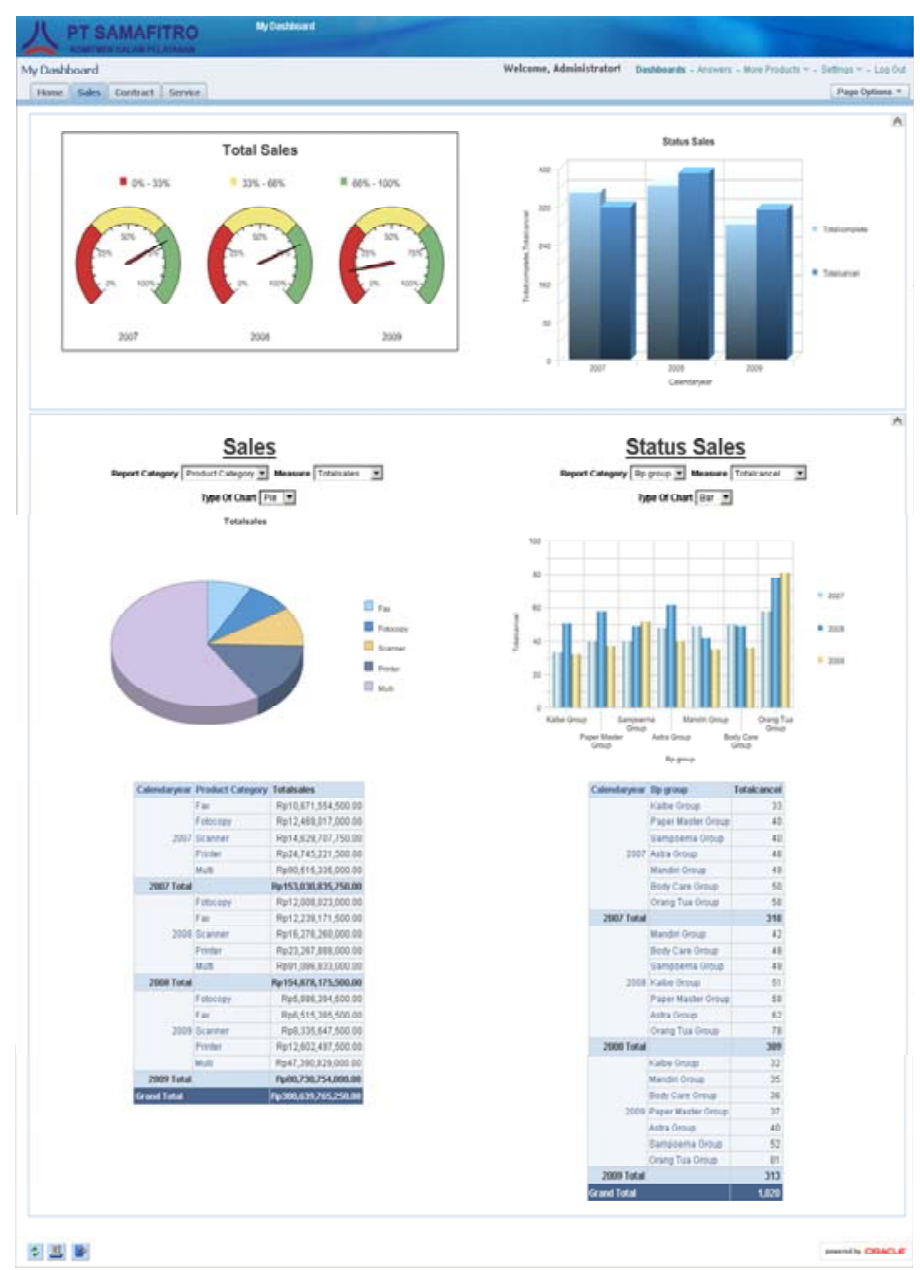

Gambar 7. Tampilan layar dashboard penjualan. 


\section{PENUTUP}

Setelah dilakukan analisis dan penelitian pada PT. S, dapat ditarik kesimpulan berdasarkan sistem yang ada saat ini bahwa eksekutif PT. S kesulitan untuk menghasilkan laporan secara menyeluruh karena letak database tersebar. Proses pengambilan keputusan juga terhambat karena laporan yang dihasilkan belum dapat memenuhi kebutuhan pihak eksekutif dan hanya memiliki sebuah dimensi. Selain itu, waktu yang diperlukan untuk menghasilkan laporan cukup lama karena database yang digunakan sangat kompleks. Aplikasi yang digunakan PT. S saat ini memiliki struktur tabel yang kompleks sedangkan aplikasi data warehouse yang dirancang menyederhanakan struktur tabel tersebut sehingga dapat mempersingkat waktu yang diperlukan untuk menghasilkan laporan. Aplikasi data warehouse dapat memberikan informasi mengenai penjualan, penyewaan, dan service kepada eksekutif dalam bentuk tabel dan grafik yang disatukan ke dalam dashboard sehingga memudahkan eksekutif untuk melihat informasi dan mempercepat pengambilan keputusan.

\section{DAFTAR PUSTAKA}

Connolly, T. \& Begg, C. (2005). Database Systems: A Practical Approach to Design, Implementation, and Management, (4th ed.). Boston: Addison Wesley.

Hollander, Anita S., Denna, Eric L., and Cherrington, J Owen. (2000). Accounting, Information Technology, and Business Solutions, ( ${ }^{\text {nd }}$ ed.). Raffles, Singapore: McGraw Hill International.

Inmon, W. H. (2005). Building the Data Warehouse, (4 ${ }^{\text {th }}$ ed.). Indianapolis: Wiley Publishing.

Kimball, Ralph, and Ross, Margy. (2002). The data Warehouse Toolkit: The Complete Guide to Dimensional Modeling, ( $2^{\text {nd }}$ ed.). Toronto, Canada: John Wiley and Sons.

Whalen, E., Garcia, M., Thompson, D. (2001). Microsoft SQL Server 2000 Performance Tuning Technical Reference. Washington: Microsoft Press. 